\title{
FORMATION OF THE HABSBURG-OTTOMAN FRONTIER IN THE DANUBIAN REGION: BUDA, 1541
}

\author{
GUSTAV BAYERLE \\ Indiana University, Bloomington, IN, \\ USA
}

On July 17, 1540 John I, the last Hungarian speaking King of Hungary, died. Stephen Werbőczy, his chancellor ventured to Istanbul to ask Sultan Suleiman for approval of naming John Sigismund, the infant son of the late king, as the new King of Hungary. This request was contrary to the agreement made in the secret Treaty of Várad of 1538 in which John I pledged that after his death Ferdinand will inherit his share of Hungary. Soon, Suleiman acknowledged John Sigismund as King John II just as the Habsburg General Vels besieged Buda to support Ferdinand's claim to the throne. In December Werbőczy returned from Istanbul and announced that Suleiman was planning a campaign in Hungary but the news did not stop Ferdinand; in May 1541 his army renewed the siege of Buda.

Sultan Suleiman arrived at Buda on August 26 and, after defeating the withdrawing Habsburg army - exactly 15 years after his victory at Mohács on August 29,1526 - his army entered the castle without opposition. There he announced that he would continue to protect John II as the ruler of an enlarged Transylvania but will make Buda the seat of a newly formed Ottoman province under the command of Suleiman Pasha. For the protection of John II's rule he imposed on Transylvania a levy of 10,000 ducats annually. After a few weeks the Sultan left Hungary leaving behind a garrison of 3,000 soldiers.

Ferdinand refused to acknowledge the status of King John II and soon besieged Pest in 1542 compelling Sultan Suleiman to lead a new campaign to Hungary in 1543. In order to protect the military route between Buda and Belgrade he widened the narrow passage by taking Siklós, Pécs, Esztergom, Tata, and Székesfehérvár and make Vilayet-i Budin an indisputable province. In four years the de facto partition became recognized internationally. In the Treaty of Edirne of 1547, Emperor Charles V and Sultan Suleiman agreed to a truce for five years and both acknowledged the status quo in Hungary. The envoy of the emperor promised the payment of an annual levy of 30,000 ducats in the name of King Ferdinand for keeping the west and northwest parts of Royal Hungary as his share. The long process of dismantling the Medieval Hungarian Kingdom - a process 
that began in 1521 with the Ottoman conquest of Nándorfehérvár/Belgrade - was completed.

Hungary remained partitioned for 150 years. In 1686-1699, in a series of fierce combats, the armies of the Holy League under the leaderships of Prince Eugene of Savoy and Count Louis of Baden wrested the region out of Ottoman control. An independent Hungary was of course inconceivable; the newly conquered territories were to be integrated into the Habsburg Empire. Not counting the short intervals of self-determination under Rákóczi and Kossuth, the House of Habsburg reigned over Hungary until 1918.

The year 1541 was indeed the turning point in the thousand-year-existence of the Hungarian nation dividing it into a period of sovereignty and a period of dependency. But it was only in the twentieth century that historians made 1541 the pivotal year. National tradition has regarded the tragic events of August 29, 1526 as the time when the Medieval Hungarian Kingdom reached its end. The carnage on the battlefield and the massacre of the prisoners, the death of seven archbishops and bishops, twenty-eight barons, 3,000 of the gentry cavalry, 10,000 of the professional infantry and - above all - the tragic death of the young king Louis II made August 29, 1526 the day when "everything was lost." Every schoolchild in Hungary could recall the immortal line of Károly Kisfaludy:

Nemzeti nagylétünk nagy temetője, Mohács!

[Mohács, the great graveyard of our national existence!]

450 years after Mohács, the literary historian Tibor Klaniczay still has maintained this position saying that the death of Louis II made the elections of two competing kings possible and in this way it precipitated the partition of the kingdom and the ensuing loss of national independence. ("Mi és miért veszett el Mohácsnál?" [What was lost at Mohács and why] in Kortárs, 1976, 783-796.)

Others, most notably Ferenc Szakály, the leading specialist of the period, have pointed out that the loss of Nándorfehérvár/Belgrade in 1521 sealed the fate of Hungary. In 1456 that fortress was heroically defended by János Hunyadi who defeated the Ottoman legions of Mehemmed II under its walls. Two generations later it was virtually abandoned by the central administration of Hungary when they did not come through with the needed financial and military aid. Its garrison defended the walls as long as it was possible. On the day of surrender - it also happened on August 29 - only 72 of the original 1500 professional soldiers were still alive and well enough to retreat. Nándorfehérvár was the linchpin in the fortification system of the southern border defense. With its loss the road to Buda was open without any stronghold on the path of an invading army. Of equal importance were the ineffectual measures of the Hungarian king that signified for the Turks that the earlier Hungarian resolve and determination to protect their 
land were broken. Hungarians were still heroic enough to die for their country but not sagacious enough to muster a successful defense of it. As Szakály saw it, with this victory the eventual downfall of the Hungarian Kingdom became inevitable. After 1521 there was nothing King Louis II could have done that would have stopped the coming Ottoman expansion to the Great Plains and Buda. Already the subtitle of his article on the subject makes his views unmistakable. ("Nándorfehérvár, 1521: The Beginning of the End of the Medieval Hungarian Kingdom," in: Hungarian-Ottoman Military and Diplomatic Relations in the Age of Süleyman the Magnificent. Ed. Géza Dávid and Pál Fodor, Budapest, 1994, 47-76.)

In the last decades of the nineteenth century some Hungarian historians - notably Ferenc Salamon (see his Magyarország a török hóditás korában [Hungary in the Era of Ottoman Domination], Budapest, 1886) - began to question the traditional view that regarded the tragedy at Mohács and the subsequent Ottoman conquest as unavoidable. Around this time Turcologists like József Thúry published Hungarian translations of Ottoman narratives and administrative sources on the Era of Suleiman. Instead of looking at the events of 1521 and 1541 from a purely Hungarian point of view, they attempted to reconstruct the Ottoman perception of the events. They looked at Ottoman claims that emphasized the defensive character of the conquest and found them plausible. Sultan Suleiman and the Sublime Porte wrote several missives to Hungarian and Western dignitaries stating that he was compelled to enter Buda in order to prevent the Habsburgs from taking it and that Suleiman was personally obliged to protect the kingship of John Sigismund. The Sublime Porte maintained that they would have preferred to have relations with a united and independent Hungary tied to the Ottoman Empire by a treaty of amity and friendship; a Hungary strong enough to defend itself against the Habsburg threat; a country that would constitute a buffer zone between the Ottomans and the Habsburgs. Salamon was inclined to trust the Turkish documents since the Ottoman Empire had already created such autonomous vassal principalities in Wallachia and Moldavia. He argued that Hungary was even further away from the core Ottoman lands of Anatolia, and that the Ottomans did not have enough troops to make a perpetual occupation of Hungary feasible. This sounded like a realistic assumption to him since - as he noted - the Turks did not make any attempts to convert Hungarians to Islam in order to make them loyal Ottoman subjects. In the inter-war period Sándor Takáts presented the Turkish world in Hungary in like fashion. After World War II, Tayyib Gökbilgin and Nejat Göyünç of Istanbul University in Turkey rekindled Salamon's lines of argument. They argued that Suleiman understood the immense material and manpower cost of occupying Hungary and for this reason he was unwilling to do so; in 1541 he did it anyway as his response to Habsburg aggression in the region. Göyünç published some of the annual budget summaries of the Province of Budin and proved that year after year 
local Ottoman income from Hungary was not sufficient to cover the expenses; the central treasury in Istanbul had to send the total revenue from Egypt to Buda to balance the local budget, consisting mostly of garrison salaries.

Géza Perjés, a Hungarian expert in military history, worked out a detailed thesis about why most of Hungary fell outside of the "action radius" of Ottoman military might. In his monograph Mohács (Budapest, 1979) he measured the distance between Istanbul and Buda, the daily progress of a complex military war engine of more than 100,000 men, and the logistic problems of providing supplies through the mountainous Balkans and the marshland region of southern Hungary. He demonstrated that for a moving army of this size foraging from the local inhabitants would not be sufficient because of the fact that the military route crossed through sparsely populated regions. Supply problems could have been surmounted by establishing military depots on the route in advance; but the distance could not be shortened. The Ottoman Empire was centrally organized and Istanbul had to be the starting point of a major campaign. Furthermore the army could not start before April since they marshaled the feudal cavalry from several Asian provinces. The Ottoman forces usually arrived at Belgrade in July and they had to complete their task by October before the onset of cold, rainy weather. The small Hungarian fortresses further to the north-west could not stop the Ottoman advance but they could slow it down considerably. At best the Ottomans had forty to fifty days to engage the enemy; there was simply not enough time to break the resistance of a determined opposing army trained in the art of strategic withdrawal and avoidance of pitched confrontation. According to Perjés this extreme time constraint was known to Suleiman and for this reason he attempted to avoid a direct military occupation of Hungary as long as it was feasible. In this view, the offers of compromise to establish a vassal yet autonomous Hungarian state were sincere and Louis II should have considered them seriously.

The propagators of this type of conceptualization put the responsibility for the demise of the Medieval Hungarian Kingdom straight on the shoulders of the Hungarian government. The king and the Hungarian magnates should have understood the perilous state of Hungary. They should have fortified Nándorfehérvár before 1521 with a larger garrison; the military payments should have been the highest priority of the treasury. These historians blame the Hungarian court for the suspension of diplomatic negotiations. The first two campaigns of Suleiman those of 1521 and 1526 - were both provoked by the arrest of Behram çavuş, the Ottoman envoy who delivered Suleiman's offer of cooperation. The Hungarian government should have understood the need for compromise in order to save the territorial integrity of the Kingdom. Even if such a compromise could not have worked in the long run it would have given some time for Hungary, perhaps even a few decades. In hindsight, we know that Ottoman decline had started already in 
the 1550s and that after the death of Suleiman at Szigetvár in 1566, his successors had little inclination for campaigns in Central Europe.

Of course, no one in Europe at the time of Mohács could have anticipated such radical change in Ottoman military disposition. Nevertheless, for Hungary, compromise was the only viable alternative; all other options were manifestly futile. Some Hungarian historians have searched for a moral rationale stating that for the Hungarians - who were deeply rooted in Western Christianity for half a millennium - a compromise with the Muslim Turks, the archenemy of Christendom, was simply not conceivable. Perhaps. But let me note that a compromise was not beneath the "most Catholic king" Francis I, King of France who made an alliance with Sultan Suleiman when it served his anti-Habsburg policy. As one result of the alliance the entire Ottoman fleet wintered in Toulon in 1543.

To a modern student of the history of sixteenth-century Hungary the detainment of the Ottoman envoy in Buda by Louis II is inexplicable. Granted international diplomacy was at its beginnings in contemporary Europe and rules of conduct for the diplomatic personnel were not clearly defined. Yet it should have been known in Hungary that detaining a diplomatic envoy was a grievous matter; that the Ottomans often signaled the end of a truce by arrests of envoys. It should be taken for granted that the Hungarian government had no intention at this time to declare war against the Ottoman Empire. Why then the mistreatment of the Ottoman envoys? No satisfactory explanation has been offered by anyone on this subject except that it expressed a "non-negotiable" stance against any compromise with the Sublime Porte.

István Nemeskürty, the noted film critic and literary historian, wrote two highly popular essays on the critical years of 1526-1552, Ez történt Mohács után [This is what happened after Mohács] (Budapest, 1966) and Elfelejtett évtized: 1542-1552 [Forgotten decade: 1542-1552] (Budapest, 1974). He lacks training in historical methodology but writes very well in a populist style. His hypothesis is a continuation of the second school of thought. In his view the Hungarian gentry was categorically responsible for the events of Nándorfehérvár, Mohács and Buda. With foresight and solidarity they could have defended Nándorfehérvár, they could have won at Mohács, and even after the establishment of the Province of Budin they would have had the opportunity to chase out the Turks from Hungary. They could not accomplish these imperative missions because of the traditional Hungarian vices; dissension and factionalism, constant squabble, greed, and a lack of common purpose. For those unacquainted with Hungarian literature his extreme selftorture would be unfathomable; but Hungarians are familiar with this "mea culpa" Ady-ist "Nekünk Mohács kell" [We deserve Mohács] mentality.

Professional historians reacted strongly against Nemeskürty's denunciation of the Hungarian nobility accusing him of distortion; that he deliberately eschewed 
evidence contrary to his premises. Pál Fodor's essay on the subject, Magyarország és a török hóditás [Hungary and the Turkish conquest] (Budapest, 1991) is the response of a Turcologist, who has meticulously culled Ottoman narrative and archival sources. He demonstrated that raids and military campaigns against the infidels were deeply imbedded in the Ottoman collective consciousness; already in 1938, Paul Wittek called it the "raison d'être" of the Ottoman state. Compelled by the legacy of his ancestors and also by the traditions of Medieval Islam, Sultan Suleiman could not have changed this policy of expansion to a policy of peaceful coexistence without courting major dissent - even mutiny - among his soldiers. Fodor also described the Ottoman method of gradual conquest originally formulated by Halil Inalcik. According to this theory, Ottoman expansion traditionally took place in three stages:

i. perennial raids across the borders causing havoc and a sharp decrease in the population of the frontier region;

ii. defeat of the central army of the target country in a pitched battle and elimination of the ruling dynasty, yet with the continuance of a semi-autonomous state;

iii. after a generation of vassal status, complete integration of the region into the body of the empire.

In the past this three-stage method of conquest had been successfully employed by the Ottomans in Anatolia and in the Balkans. By providing an extended transitional period after the initial shock of military defeat, the Ottomans secured a relatively peaceful integration of subject ethnic communities with many of the local traditions remaining intact.

The Inalcik theory - as espoused by Fodor - explains the five-year hiatus after the loss of Nándorfehérvár and the cautious retreat from Buda in 1526. It also confirms that any compromise with Sultan Suleiman would have been ephemeral; with the illusionary compromise the Turks would have secured Hungary and used it as base of operations with little actual expense. The task of besieging and taking Vienna would have been their next logical maneuver. After the conquest of Vienna, Hungary would have shared the fate of Serbia and would have been integrated into the Ottoman Empire. With this final argument Fodor's interpretation of the events joins Szakály's theory; after the loss of Nándorfehérvár in 1521, the demise of the Hungarian Kingdom was inevitable. Heroic resistence or compromise - whatever alternatives Louis II could have chosen, the end would have been the same.

The varying interpretations of the partition of Hungary by capable historians who start with the same basic facts yet arrive at different conclusions are not uncommon in historiography. In the Hungarian case one must also consider the circumstances of the formation of the disparate interpretations. In the late nineteenth century there existed a friendly sentiment among the anti-Habsburg faction 
of Hungarian intellectuals who remembered fondly the Ottoman Empire that provided safe harbor for Rákóczi and Kossuth when their causes were lost. Most Hungarian Turcologists in that period depicted Ottoman history in friendlier terms than it was customary in earlier times. The Mohács dispute of the 1970s was similarly influenced by modern parallels. Some people might have seen similarities between the compromise with the Ottoman Empire and the compromise with the Soviet Union. Although I have been acquainted with most of the historians mentioned here I never thought it prudent to ask about this matter from them. Perhaps it is worthwhile to mention though that - in a different context - Lajos Fekete published a short essay in 1947 with the title, Magyarság, törökség: Két világnézet bajvívói [Hungarians and Turks: The champions of two ideologies]. He told me confidentially in 1965 that when he wrote Turks he really meant Soviet ideology.

Every generation rewrites its perception of the past since the main use of history is the justification of the present. It is time for post-Communist Hungarian historians to reconsider the demise of the Medieval Hungarian Kingdom. In my opinion, such reassessment should focus on two major themes; the first one is internal and the second one international although the two are inter-connected.

The first issue pertains to Hungarian society in the first decades of the sixteenth century. A society can be modeled as a structure of interrelated institutions. In the case of a kingdom the linchpin of the structure is - of course - the institution of kingship. In Hungary, numerous historians have observed that the role of the king changed radically between the reigns of Matthias and Louis II. By 1520 Louis II had lost most the economic base, the military authority and the policy-making power of his predecessors. His position was compromised, even undermined to the extent that he had no latitude for long range policy planning. Whatever he did was just an ad-hoc response to some crisis. Conjuring the chimera of the "traditional vices of the Hungarian nobility" is not a serious assessment of the complex forces that caused the deterioration of this fundamental institution.

Recently I have read a fascinating monograph by Attila Zsoldos, Az Árpádok és alattvalóik: Magyarország története 1301-ig [The Árpáds and their subjects: The history of Hungary till 1301] (Debrecen, 1997). To my knowledge, he is the only Hungarian historian who has made an attempt to write an institutional history; alas, he did it for an earlier period. Monographs like his are essential for a better understanding of the structural changes in society. I am looking forward to scholarly research of this type for the age of Jagellos.

The second issue concerns the international relations of Hungary in the 1520s. Much ado was made by Hungarian historians about the feasibility of the compromise offered by Sultan Suleiman. Much less attention was paid to the threat Hungary faced from the West even though some contemporaries considered the Habsburg blueprint for the annexation of Hungary more grievous than the Otto- 
man menace. It should be transparent to observers of the period that the Austrian Habsburgs targeted Hungary for expansion and that even without Ottoman pressure Hungarian sovereignty was in serious peril. Hungarians could not choose between Scylla and Carybdis and their indecisiveness was the real cause of the partition of their kingdom.

At this critical stage, diplomacy in Hungary was without perspectives. Her diplomatic endeavors amounted only to requests of financial aid against the Turkish menace without indicating anything in return. In the early sixteenth century diplomatic activities in Europe reached new heights. Alliances were formed and broken in West Europe with rapidity; eventually even the Ottoman Empire was drawn into the fight against the Habsburgs. The Holy League of 1511 was formed not against the Turks - as in the seventeenth century - but against the French in order to drive them out from Italy. Under Francis I (1515-1547) France was searching for allies and concluded treaties with all potential anti-Habsburg regimes. Yet, in Louis II's reign Hungary was not a player in the diplomatic ventures in spite of the manifest need for international affiliations. Through the double marriage contract with Archduke Ferdinand, King Louis II was commited to the Habsburg side; but it was a one-sided obligation that did not include shared responsibility for the defense of the integrity of Hungary against Turkish attacks. In truth, at that time Austria had neither the inclination nor the military strength to effectively protect Hungary. When Hungary needed it most she was left alone to face the Ottoman onslaught. Possibly the reasons for the ineffective diplomatic relations could be found in the deteriorated condition of central authority; nevertheless, this failure of Hungarian diplomacy to attract international alliances warrants further investigation. Without substantial foreign assistance - military, financial or diplomatic - Hungary was not able to withstand the increasing pressure from two sides of her borders; her collapse was predictable even without the Mohács disaster.

The burden of the subversion of Hungarian royal authority and the lack of diplomatic perspectives proved to be fatal to Hungarian sovereignty. The decline of Hungarian central authority happened at the worst possible time; at the time of the global formation of the frontier between two superpowers, the Habsburgs and the Ottomans. Because of the simultaneous pressures from west and south, Hungary ended in the worst possible position with the line of demarcation going through her center. 